\title{
Growth Rhythms in Pouch-Young of the Agile Wallaby in Australia
}

\author{
M. L. DUDZINSSKI, A. E. NEWSOME \& J. C. MERCHANT
}

Dudziński M. L., Newsome A. E. \& Merchant J. C.: Growth rhythms in pouch-young of the agile wallaby in Australia. Acta theriol., 23, 26: $401-411$ [With 4 Tables \& 4 Figs].

Tropical agile wallabies, Wallabia agilis (Gould) reared in a cool climate had a pouch-life which lasted about seven months, during which they showed periodic changes in growth rates. An exponential function fitted the overall pattern of growth of individuals, and an additional cosine function the periodic growth about it. Though young were too small to measure in the first week of life, the growth equations indicated an initial decline below the exponential curve then. There were three amplitudes in growth occuring at mean ages of 45 , 103 and 167 days. Periodicity was most pronounced in slowly growing animals born in winter, which is cold to mild, and born to young light mothers. The periodic patterns did not alter as the seasons changed during pouch-life. Three amplitudes were regressed on selected minimum temperatures in the first months of life and on mother's weight and age. The first harmonic amplitude was related to minimum temperatures in the first week of life of a young. Two other amplitudes were related to mother's condition and age, to temperature levels and to temperature changes.

[CSIRO Div. Mathemat. Statist., P.O. Box 1965, Canberra, Australia (MLD); CSIRO Div. Wildl. Res., P.O. Box 84, Lyneham, Canberra, Australia (AEN, JCM).]

\section{INTRODUCTION}

The periodicity in post natal growth curves of eutherian mammals is well documented (Wood et al., 1962; McEwan \& Wood, 1966; M c Ewa n, 1969; Grizzle et al., 1974). However there is no published evidence of this phenomenon in marsupials. This paper suggest its existence in pouch young using growth curves of Agile Wallabies as evidence.

The agile wallaby (Wallabia agilis) is a tropical animal that can breed all year around; the young stay in the pouch for about seven months (M e r chant, 1976). A colony of them has been reared in Canberra to study reproduction and to develop age estimation techniques for an ecological study in northern Australia (B o l t o n, in prep.). Compared with our experience in raising other macropodids at Canberra, growth rates were highly variable and periodic.

Growth of the agile wallaby pouch young in the exotic environment [401] 
of Canberra was analysed with respect to the cold ambient temperature and to qualities of the mother.

\section{METHODS}

Body measurements were taken weekly throughout pouch-life on 20 young born to a colony of agile wallabies whose founders were furred young collected about $100 \mathrm{~km}$ south-east of Darwin. They had a total of seven mothers and four or five fathers, and were born at various times of the year. Sixteen of the young were included in five sets of siblings.

Statistical analysis cansisted of fitting a simple exponential growth curve (carrier function) to each animal. The carrier function was then augmented by a cosine type growth rhythm component. Three amplitudes suggested by the second equation were regressed on a set of environmental variables using Principal Component Analysis $(P C A)$ to reduce dimensions. The details of the $P C A$ are expounded in Appendix A.

\section{RESULTS}

\subsection{Gross Variation in Growth}

The slowest growing animals were born in the cold months (Fig. 1). A $2 \times 2$ contingency table was constructed from the data: those animals heavier or lighter than $600 \mathrm{~g}$. versus those born between October and

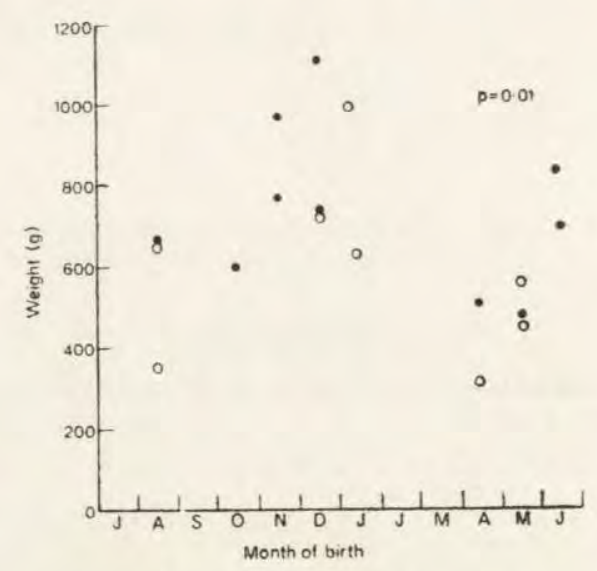

Fig. 1. Weights of 170 day old pouch-young and the months of birth. Closed circles, males; open circles, females.

March (warm) or April and September (cold). An exact test showed that the probability of these differences occurring by chance alone was only 0.01 . At 170 days of age, near the end of pouch-life, such animals were as little as one third to one half the weight of young born in summer 
(Table 1). The weights of young at that age were highly correlated $(r=0.59$, $p<.01)$ with minimum ambient temperatures in the early part of their lives (Table 1), and also with the weights of their mothers then (Table 1, Fig. 2). Siblings showed the same trends in body weight with mean minimum ambient temperature in the first week of life (data in Table 1). Also, heavy mothers consistently produced heavier young than others (cf. young Nos. 3, 5, 12 and 19 with Nos. 7, 9, 17 and 20 in Table 1).

\subsection{Cyclical Variation in Growth}

The simple growth-curve of leg length $(Y \mathrm{~mm})$ on age ( $X$ days) had the form:

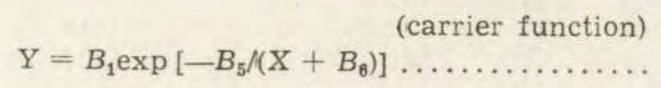

where $B_{1}$ was the hypothetical maximum length of the leg of each wallaby, $B_{5}$ was the relative growth rate, and $B_{6}$ locates the curve on the

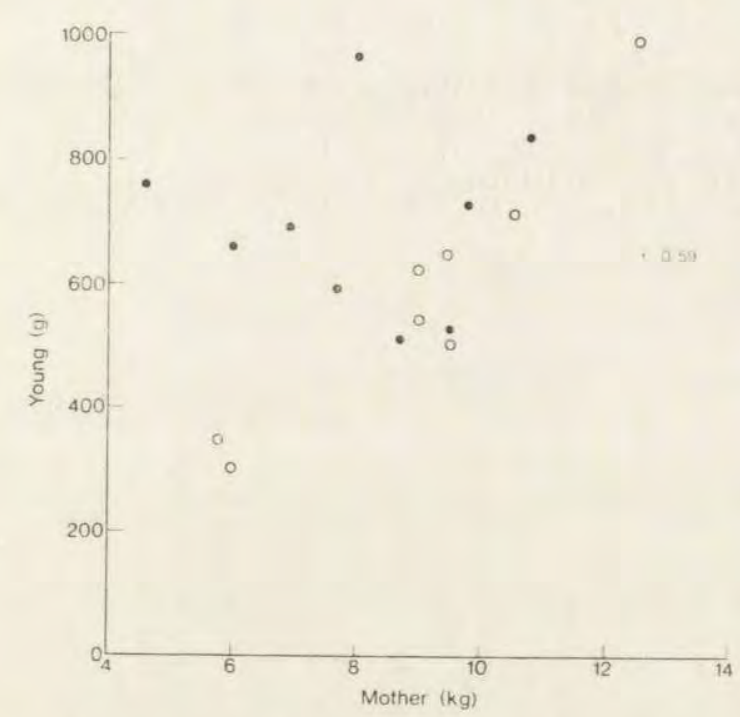

Fig. 2. Weights of 170 day old pouch-young and their mothers $(\mathrm{kg})$ at partum $(r=0.59 ; P<0.01)$. Closed circles, males; open circles, females.

$X$-axis. Deviations from the fitted curve appeared to be, in most cases, continuous and harmonic, with three peaks about Equation 1; one example using animal 2 is shown in Fig. 3 . The detected wave function was 1.5 cycles long during the pouch-life, two peaks being above the 
Table 1

Some statistics at birth

\begin{tabular}{|c|c|c|c|c|c|c|c|}
\hline \multicolumn{5}{|c|}{ Young } & \multicolumn{2}{|c|}{ Mother } & \multirow[b]{3}{*}{$\begin{array}{l}\text { Weight } \\
\text { (kg) }\end{array}$} \\
\hline \multirow{2}{*}{$\begin{array}{l}\text { No. } \\
\text { (Symbols } \\
\text { show } \\
\text { sibilings) }\end{array}$} & \multirow[b]{2}{*}{$\begin{array}{l}\text { Birth- } \\
\text { month }\end{array}$} & \multirow{2}{*}{\multicolumn{3}{|c|}{$\begin{array}{ccc}\text { Weight at various } & \text { ages }(\mathrm{g}) \\
\text { Day } 60 & 105 & 170\end{array}$}} & \multicolumn{2}{|c|}{ At parturition } & \\
\hline & & & & & $\begin{array}{c}\text { Age } \\
\text { (days) }\end{array}$ & $\begin{array}{l}\text { Molar } \\
\text { eruption }\end{array}$ & \\
\hline \multicolumn{8}{|c|}{ MALES } \\
\hline $1 *$ & June & 50 & 150 & 693 & 475 & 1.8 & 6.9 \\
\hline $2+$ & Aug. & 38 & 158 & 661 & 427 & 1.6 & 6.0 \\
\hline $3 \#$ & Nov. & 48 & 191 & 973 & 475 & 1.4 & 8.0 \\
\hline $4+$ & May & 38 & 129 & $485^{*}$ & 1043 & 2.6 & 9.5 \\
\hline $5 \#$ & June & 44 & 168 & 838 & 685 & 2.4 & 10.8 \\
\hline $6 \times$ & Oct. & 43 & 156 & 598 & 995 & 3.0 & 7.8 \\
\hline 7. ** & Apr. & 42 & 150 & $500^{*}$ & 1009 & 2.6 & 8.7 \\
\hline $8 \times$ & Nov. & 44 & 160 & 645 & 1416 & 3.0 & 9.7 \\
\hline $9 * *$ & Dec. & 49 & 161 & 731 & 1227 & 2.8 & 9.5 \\
\hline $10+$ & Jan. & 42 & 118 & - & 1092 & 2.8 & 9.5 \\
\hline 11 & Nov. & 41 & 167 & 766 & 364 & 1.0 & 4.6 \\
\hline $12 \#$ & Dec. & 47 & 207 & 1104 & 1965 & 3.6 & 13.5 \\
\hline \multicolumn{8}{|c|}{ FEMALES } \\
\hline 13 & Aug. & 26 & 107 & 353 & 383 & 1.4 & 5.8 \\
\hline $14 *$ & Jan. & 42 & 165 & 624 & 732 & 2.0 & 9.0 \\
\hline $15+$ & Aug. & 42 & 157 & 650 & 790 & 2.6 & 9.5 \\
\hline $16+$ & Apr. & 41 & 83 & 301 & 448 & 1.4 & 6.0 \\
\hline 17 ** & May & 39 & 148 & 553 & 660 & 2.0 & 9.0 \\
\hline $18 \times$ & May & 38 & 131 & $452^{1}$ & 1224 & 3.0 & 9.5 \\
\hline $19 \#$ & Jan. & 50 & 215 & 989 & 1272 & 3.0 & 12.5 \\
\hline $20 * *$ & Dec. & 47 & 194 & 717 & 1983 & 3.6 & 10.5 \\
\hline \multicolumn{8}{|c|}{ Significance levels of the correlation } \\
\hline of weight & 70 days & and enviro & nmental & variables & NS & NS & $<0.05$ \\
\hline
\end{tabular}

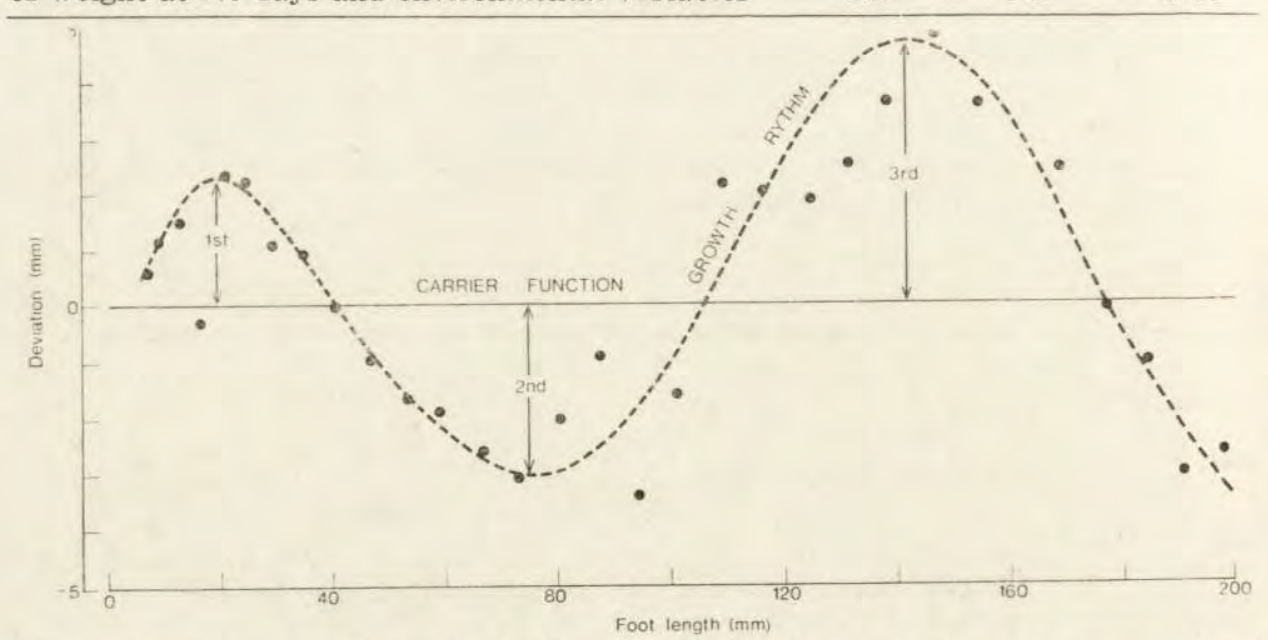

Fig. 3. An example of growth rhythm of leg length $(\mathrm{mm})$ of pouch young No. 2 constructed from the difference between Equations 1 and 2. The carrier function (Eq 1) is represented as a straight line for convenience. Three amplitudes indicated.

\footnotetext{
1 Weight at 162 days of age.
} 
and during pouch-life.

Minimum temperatures centigrade

\begin{tabular}{|c|c|c|c|c|c|c|c|c|}
\hline \multirow{2}{*}{$\begin{array}{c}12 \text { weeks } \\
\text { later } \\
\text { Weight }(\mathrm{kg})\end{array}$} & \multirow[b]{2}{*}{ On birthday } & \multirow[b]{2}{*}{ WK 1} & \multicolumn{4}{|c|}{ Weekly means post-partum } & $\theta$ & \multirow[b]{2}{*}{16} \\
\hline & & & 2 & 3 & 4 & 8 & 12 & \\
\hline 8.4 & 3.9 & 1.3 & 0.7 & -0.7 & -3.7 & 0.0 & 0.2 & 0.9 \\
\hline 7.0 & -1.1 & 0.5 & 0.7 & -1.3 & 0.2 & 7.1 & 4.4 & 8.5 \\
\hline 10.0 & 6.7 & 4.4 & 4.1 & 2.2 & 4.8 & 7.8 & 9.1 & 5.9 \\
\hline 10.0 & 3.3 & -0.5 & 5.1 & -1.3 & 0.9 & -2.2 & 0.8 & 1.1 \\
\hline 11.6 & -1.7 & -2.0 & 1.3 & -2.2 & 0.0 & 2.4 & 7.4 & -0.1 \\
\hline 8.5 & 6.1 & 3.4 & 6.5 & 4.3 & 5.3 & 6.1 & 6.9 & 11.2 \\
\hline 9.0 & -2.8 & -2.1 & -0.1 & -0.2 & 0.4 & -0.8 & 1.7 & 0.3 \\
\hline 10.0 & 5.0 & 6.3 & 9.9 & 9.6 & 11.1 & 11.5 & 11.1 & 14.5 \\
\hline 10.0 & 11.1 & 9.9 & 9.6 & 11.1 & 8.1 & 10.7 & 11.2 & 11.7 \\
\hline 10.0 & 9.4 & 11.7 & 12.2 & 14.5 & 11.6 & 13.2 & 6.7 & 4.2 \\
\hline 7.0 & 9.4 & 5.5 & 8.8 & 8.9 & 7.3 & 10.7 & 16.7 & 15.7 \\
\hline 14.9 & 7.8 & 10.6 & 12.2 & 10.6 & 11.7 & 17.7 & 12.1 & 8.2 \\
\hline 6.9 & $5.6 \cdot$ & 3.9 & -1.7 & 0.6 & 0.6 & 1.0 & 5.2 & 7.9 \\
\hline 8.8 & 11.1 & 13.3 & 11.2 & 8.9 & 12.2 & 11.0 & 8.8 & 3.3 \\
\hline 10.0 & 3.3 & 1.1 & -2.2 & -1.7 & -2.8 & 0.6 & 3.9 & 4.2 \\
\hline 7.2 & 4.4 & 3.5 & 3.7 & 0.9 & 2.0 & -0.5 & -0.4 & 0.9 \\
\hline 8.5 & 6.7 & 3.4 & -2.7 & 3.2 & -0.1 & -0.3 & 1.6 & 6.4 \\
\hline 9.7 & 2.8 & -0.6 & 0.9 & 1.6 & -2.0 & -2.1 & -0.7 & 1.2 \\
\hline 14.0 & 12.2 & 10.0 & 13.3 & 12.2 & 13.3 & 14.7 & 5.8 & 3.9 \\
\hline 11.5 & 10.6 & 11.9 & 11.3 & 11.7 & 13.7 & 12.8 & 7.3 & 3.9 \\
\hline$<0.001$ & NS & $<0.1$ & $<0.05$ & $<0.1$ & $<0.05$ & $<0.001$ & $<0.1$ & NS \\
\hline
\end{tabular}

smooth growth curve of Equation 1, and one below. An extra term was therefore added to the carrier function (Equation 1), the new function taken the form:

$Y=\left[B_{1}+B_{2} \cos \left(-B_{3} X+B_{4}\right)\right] \exp \left[-B_{5} /\left(X+B_{6}\right)\right]$

The multiplicative model of Equation 2 was adopted as amplitudes generally increased with animal's age (see Fig. 3).

Equation 2 may be written as $Y=A_{x} B_{x}$, where $A_{x}=B_{1}+B_{2} \cos \left(-B_{3} X+\right.$ $\left.+B_{4}\right)$ is the asymptotic value of leg length, and $B_{x}=\exp \left[-B_{5} /\left(X+B_{6}\right)\right]$ is the ageing factor. Within $A_{x}, B_{2} \cos \left(-B_{3} X+B_{4}\right)$ is defined as "Growth Rhythm". The statistical improvement of fitting Equation 2 over Equation 1 to the data is presented in Table 2. The test used to demonstrate improvement was a likelihood ratio test: assuming normality of the deviates, $\lambda=2 \mathrm{~N} \ln \left(S_{1} / S_{2}\right)$ is approximately distributed as a Chi-square with three degrees of freedom $(\mathrm{R}$ a o, 1965). (Here $\mathrm{N}$ denotes the sample size, and $S_{1}$ and $S_{2}$ are the standard deviations of the residuals from Equations 1 and 2 respectively. 
Table 2

Statistical summaries for two equations for growth.

\begin{tabular}{|c|c|c|c|c|c|c|c|c|}
\hline \multirow[t]{2}{*}{ Animals } & \multirow[t]{2}{*}{$\begin{array}{c}\text { No. of } \\
\text { observations }\end{array}$} & \multirow{2}{*}{$\begin{array}{l}\text { Significant gain of } \\
\text { Equ. } 2 \text { over Equ. } 1 \\
\text { measured by } \chi^{2}\end{array}$} & \multicolumn{3}{|c|}{$\begin{array}{l}\text { Harmonic amplitudes } \\
\text { Amplitudes (mm) }\end{array}$} & \multicolumn{3}{|c|}{$\begin{array}{c}\text { of Equation } 2 \\
\text { Ages of young } \\
\text { then (days) }\end{array}$} \\
\hline & & & 1st & 2nd & $3 \mathrm{rd}$ & $15 t$ & 2nd & $3 \mathrm{rd}$ \\
\hline & \multicolumn{8}{|c|}{ MALES } \\
\hline 1 & 29 & $* * *$ & 2.1 & -2.6 & 4.1 & 46 & 103 & 175 \\
\hline 2 & 31 & $* * *$ & 2.4 & -3.1 & 4.8 & 41 & 104 & 174 \\
\hline 3 & 26 & ** & 1.1 & -.16 & 3.0 & 42 & 106 & 150 \\
\hline 4 & 24 & $* *$ & 2.1 & -.16 & - & 52 & 115 & - \\
\hline 5 & 30 & $* * *$ & 2.5 & -3.0 & 3.2 & 45 & 101 & 178 \\
\hline 6 & 29 & $* * *$ & 1.6 & -2.3 & 2.7 & 46 & 113 & 173 \\
\hline 7 & 22 & - & 1.1 & -1.1 & - & 71 & 120 & - \\
\hline 8 & 17 & - & - & - & - & - & - & - \\
\hline 9 & 26 & $* *$ & 1.2 & -0.7 & 1.1 & 42 & 105 & 171 \\
\hline 10 & 13 & $\ldots$ & - & - & - & - & - & - \\
\hline 11 & 27 & $* * *$ & 1.6 & -2.0 & 3.1 & 37 & 114 & 177 \\
\hline 12 & 25 & $* * *$ & 1.4 & -2.1 & 3.1 & 43 & 95 & 165 \\
\hline \multicolumn{9}{|c|}{ FEMALES } \\
\hline 13 & 34 & $* * *$ & 1.7 & -2.3 & 4.7 & 39 & 123 & 200 \\
\hline 14 & 24 & * & 0.6 & -0.9 & 1.1 & 41 & 83 & 136 \\
\hline 15 & 28 & $* * *$ & 1.5 & -2.7 & 4.2 & 46 & 109 & 164 \\
\hline 16 & 36 & $* * *$ & 3.1 & -6.0 & 5.1 & 69 & 118 & 181 \\
\hline 17 & 29 & $* * *$ & 1.5 & -1.2 & 2.6 & 48 & 97 & 153 \\
\hline 18 & 23 & $* * *$ & 1.5 & -1.0 & - & 50 & 100 & - \\
\hline 19 & 28 & $* * *$ & 1.5 & -2.4 & 4.2 & 53 & 88 & 158 \\
\hline 20 & 28 & $* * *$ & 1.0 & -1.4 & 3.1 & 49 & 84 & 154 \\
\hline
\end{tabular}

* $P<0.05 ; \quad$ ** $P<0.01 ;{ }^{* * *} P<0.001 \quad$ - either mother or young died

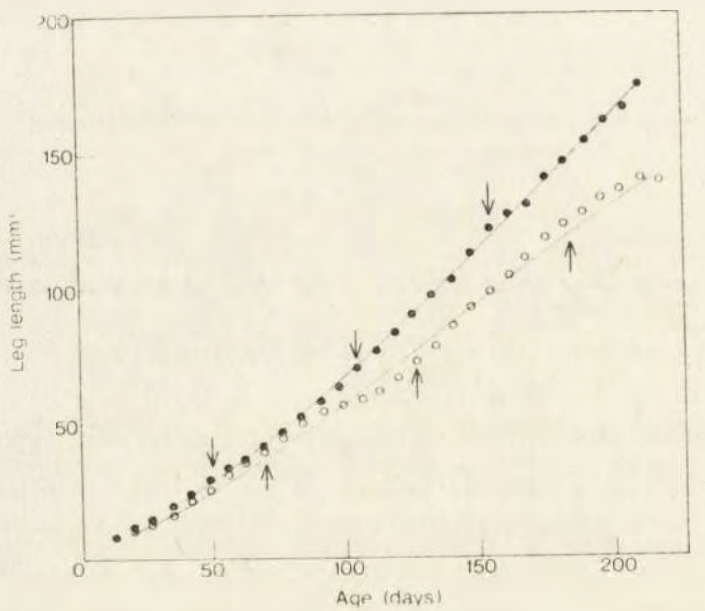

Fig. 4. An example of fast and slow growing pouch young (No. 17 and 16 showing pronounced cyclical pattern in the latter). (Arrows indicate amplitudes from the carrier function (Equation 1)). 
Equation 2 proved realistic only during growth in the pouch and not for adulthood and was used only for that part of the growth curve. It could be fitted to only eighteen of the original pouch young as no amplitudes were detectable in the growth of males No. 8 and 10 (Table 2). Accordingly their data were deleted from the subsequent regression analyses.

Also shown in Table 2 are the ages of young when amplitudes were maximal, and the sizes of those amplitudes. The maximum amplitudes of harmonics were inversely related to the overall rate of growth (e.g. see Fig. 4). Growth, in turn, was related to temperature early in life (Fig. 1) and to the mother's weight (Fig. 2). Also the coefficient of variation (CV) of the sample of the ages at which amplitude occurred was of the order of approximately $10 \%$, while the same in the size of the amplitudes was closer to $45 \%$. The 4.5 higher variation in amplitudes rather

Table 3

Significant principal components $(P C)$ in multiple regression.

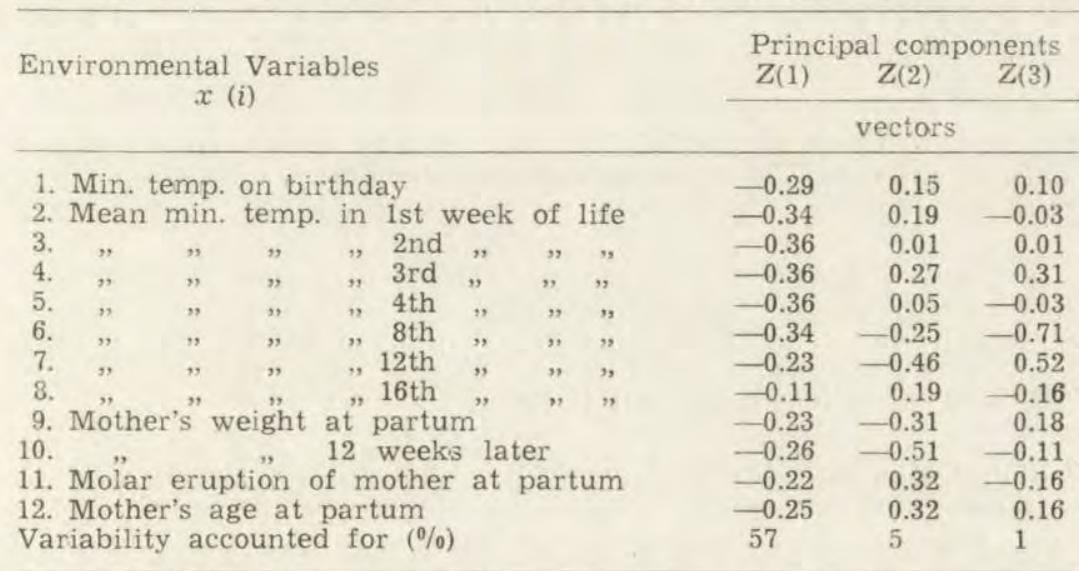

than in ages at which they occurred prompted an attempt to explore this variability. It was done by relating these amplitudes to a number of environmental variables. Twelve measurements were chosen, eight for minimum temperatures, and four for the mother (two for age and two for weight) (Tables 1 and 3 ).

The regression analysis of amplitudes on environmental variables is detailed in Appendix A. The summary of the regression of amplitudes on principal components of environmental variables is presented in Tables 3 and 4 . The first amplitude was related to minimum ambient temperature during the first week of pouch life. The second amplitua wes related to mother's weight and age, and to the general level of and 
changes in minimum temperatures in the 8th and 12th weeks of pouch life. The third amplitude was related mostly to minimum temperatures in the first eight weeks of life, but to lesser extent to the mother's age and weight also.

\section{DISCUSSION}

Young agile wallabies born in winter grew slower than those born in summer in the exotic environment of Canberra. The growth of most animals had a harmonic rhythm super-imposed upon a smooth carrier curve. These rhythms were more pronounced in the slower growing winter-born animals. They appear to have been set early in life because the pattern did not alter throughout the pouch-life of seven months nor with changing seasons.

Three harmonic amplitudes were detected in the data, the first and third being above the carrier curve. Of the environmental variables examined, those most closely related to the sizes of the harmonic amplitu-

Table 4

Regressions of three amplitudes from growth curves on significant independent variables *

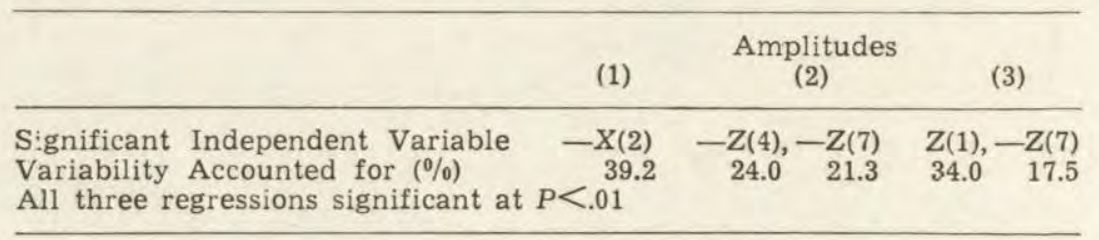

* $\mathrm{X}(2)=$ Min. temp in first week of life, and $\mathrm{Z}(i)=$ principal components.

des were the minimum ambient temperature and the mother's age and condition in the first and twelfth week of life of the young. Also, minimum ambient temperatures in the eight and twelfth weeks of life appear to have influenced the size, especially of the negative second amplitude.

The analyses indicate that the colder the temperature in the first week of life and the younger and light the mother, the more stunted and more cyclical the growth of the young. These factors may set the mean growth rate, the harmonic possibly being over-compensation for impedance in the first week of life. At birth the young weighs an average of $0.6 \mathrm{~g}$ ( $\mathrm{M}$ e r ch a n t, 1976), it is wet and unprotected and has to climb unaided to the pouch. In the red kangaroo, Macropus rufus, the young takes around three minutes on average to make this journey. In mid- 
winter neonatal agile wallaby young could be exposed to a temperature differential of $35-40^{\circ} \mathrm{C}$ or more.

The cyclic growth reported here for the young agile wallaby in Canberra appears to be related directly to the season of birth, and does not appear to be influenced by changes in the seasons during the seven months of pouch life. By contrast cyclical growth in caribou (Rangifer tarandus grenlandicus) and deer of the genus Odocoileus is annual, and related to the contrasting seasons (W o o d et al., 1962; M c Ewan \& W o o d, 1966; M cEwa $\mathrm{n}, 1968$ ). The weight and condition of the mother wallaby were also implicated in the growth rate of its young, and so nutrition my also be a proximate factor, as in laboratory rats ( $\mathrm{Grizzle}$ et al., 1974). Their Fig. 1 shows that poorly nourished, slowly growing rats has a pronounced periodic pattern of growth.

These cyclic rhythms in growth of pouch young may reflect innate growth mechanisms or they may result from metabolic changes due to cold temperature enhanced by the nutritional status of the mother.

Agile wallabies are tropical animals. In Canberra, winters are cold. Though numbers were small, the inadvertant rearing of these animals in a cold climate has indicated previously unknown growth rhythms in marsupial young. Experiments will be necessary to identify the physiological mechanism involved.

Acknowledgement: We are grateful to I. M c L e o d of the University of Waterloo for his help in formulating Growth Rhythm Equation; Drs H. Ty nda le - B is co e, B. Green and D. Shaw were very helpful in improving the manuscript. Mr. F. Knight drew the figures.

\section{REFERENCES}

1. Bolton B. L., 1974: An ecological study of the agile wallaby on the coastal plains of the Northern Territory with a comparison between improved and unimproved areas. Unpubl. M.V.Sc. Thesis, Univ. of Queensland.

2. Grizzle J. E., 1974: Multivariate analysis in biometry. Proc. 8th Inter. Biom. Conf., Constanta, Romania.

3. M c Ew a n E. H., 1968: Growth and development of the barren-ground caribou. II. Post-natal growth rates. Can. J. Zool., 46: 1023-1029.

4. M c E w a n E. H. \& Wood A. J., 1966: Growth and development of the barrenground caribou. Heart girth, hind foot length and body weight relationships. Can. J. Zol., 44: 401-411.

5. Merchant J. C., 1976: Breeding biology of the agile wallaby Macropus agilis (Gould) (Marsupialia: Macropodidae), in captivity. Aust. Wildl. Res., 3: 93-109.

6. Sea 1 H. L., 1964: Multivariate statistical analysis for biologists. Methuen \& Co. Ltd, London.

7. Ra o C. R., 1965: Linear statistical inference and its application. Wiley: New York. 
8. Wood A. J., Cowan McT. I. \& Nordan H. C., 1962: Periodicity in growth in ungulates as shown by deer of the genus Odocoileus. Can. J. Zool., 40: 593-603 .

Accepted, February $7,1978$.

\section{APPENDIX A}

The variables chosen to represent the seasons were the minimum temperature $\left({ }^{\circ} \mathrm{C}\right)$ on the day of birth of each young, and mean minima for the 1st, 2nd, 3rd, 4 th, 8th, 12th and 16th weeks post partum (Table 1). Those chosen to describe the mother were its age (days), molar eruption and weight $(\mathrm{kg})$ at partum, and the mother's weight 12 weeks later. Out of those 12 variables a matrix was obtained, which we call $[X]$. The $[X]$ matrix had been subjected to Principal Component Analysis (PCA) (S e a l, 1964) in order to reduce its dimensions by using linear combinations instead of original variables. It was hoped that PCA would simplify the interpretation. The variables of $[X]$ were in different units, hence correlations were used in PCA. All PC's were used as regressors for amplitudes and those which were significant in multiple regression are presented in Table 3 . Two maxima and a minimum occurred for most animals between 10-200 days of their pouch age, e.g. (Fig. 3). The size of amplitudes 2 and 3 were regressed in turn on the PC's. Amplitude 1 was regressed on only those variables to which it could possibly be related. The results of those three analyses are listed in Tables 3 and 4.

\section{First Amplitude}

The first amplitude was reached on average when the young was about 45 days old. Minimum ambient temperature in the early life of the young was prominent, indicating that the lower the temperature, in the first week of life $(X(2))$ the larger the deviation.

This relation was significant at $P<.01$; it is listed in Table 4.

\section{Second Amplitude}

The second amplitude was reached when the young were on average 103 days old. The $Z(4)$ and $Z(7)$, fourth and seventh Principal Components were important contributors to regression $(P<.01$ Table 4$)$. The 103 days would imply 14 th \pm 1 week. The variables significant in $\mathrm{Z}(4)$ are temperature during 12th week and mother's age and condition both at birth and at 12 th week of young's age. $Z(7)$ can be identified with temperature changes between 8 th and 12 th week.

\section{Third Amplitude}

This amplitude occurred on average at 167 days of age. $Z(1)$ and $Z(7)$ were significant Principal Components in regression $(P<.01$, Table 4$) . Z(1)$ can be identified predominantly with combined temperature effects, with the smaller addition of mother's condition relative to its age, $Z(7)$ is described above. 
Mirosław DUDZIŃSKI, A. E. NEWSOME i J. C. MERCHANT

\section{RYTM WZROSTU MEODYCH WALLABII SMUKEYCH W AUSTRALII}

\section{Streszczenie}

Tropikalne młode wallabie smukłe, Wallabia agilis (Gould) hodowane w chłodnym klimacie, spędzają $w$ torbie matki około siedmiu miesięcy. W tym czasie młode wykazały regularne oscylacyjne zmiany wzrostu. Dobrym przybliżeniem ogólnego wzrostu była zwykła nieskomplikowana funkcja logarytmiczna, ale funkcja kosinusowa lepiej oddawała periodyczność wzrostu. Trzy wahania oscylacyjne (amplitudy) wzrostu obserwowano w przeciętnym wieku 45, 103 i 167 dni. Wahania te były większe $u$ powoli rosnących osobników, urodzonych $w$ zimie $z$ matek młodych i o niskim ciężarze ciała. Oscylacje wzrostu skorelowano za pomocą regresji wielowymiarowej z minimalnymi temperaturami otoczenia pierwszych miesięcy życia w torbie matki, oraz $\mathrm{z}$ wiekiem i ciężarem matki. Pierwsza amplituda wykazała związek z minimalną temperaurą otoczenia w czasie pierwszego tygodnia życia. Dwie inne amplitudy były związane ze stanem matki, tj. jej ciężarem ciała $w$ stosunku do wieku, oraz $\mathrm{z}$ temperaturami otoczenia i nagłymi zmianami temperatur. 